2. Meyer, H., \& Mally, J. (1912). On hydrazine derivatives of pyridine carbonic acids. Monatshefte Chemie verwandte Teile anderer Wissenschaften, 33, 393-414.

3. Berezhnoy, R. V., Gribov, V. M., \& Denkovskiy, A. R. (1980). Rukovodstvo po sudebnomeditsinskoy ekspertize otravleniy. M. Meditsina, 404-405 (in Russian).

4. Chekman, I. S., Peleschuk, A. P., \& Pyatak, O. A. (1986). Spravochnik po klinicheskoy farmakologii i farmakoterapii. Kiev «Zdorov'ya», 649-650 (in Russian).

5. Kutsenko, S. A. (2012). Osnovyi toksikologii. Sankt-Peterburg, 367-368 (in Russian).

6. Korzhevskiy, D. E., Gilyarov, A. V. (2010). Osnovyi gistologicheskoy tehniki. SPb. SpetsLit, 16-20 (in Russian).

7. Pirs, Je. (1962). Gistohimija teoreticheskaja i prikladnaja. M.: Inostr. lit. (in Russian).

8. Kotsyumbas, G. I., \& Vretsona, N. P. (2018). Gistologichni ta gistohimichni zminy v pechintsi sobak za otruennya izoniazidom. Naukovyi visnyk LNUVMB imeni S. Z. Gzhytskogo, 20 (92), 197-202 (in Ukrainian).

9. Luzhnikov, E. A., \& Kostomarova, L. G. (1989). Ostrye otravlenija. M.: Medicina, 151153 (in Russian).

Рецензент - М. І. Жила, д. вет. н., ДНДКІ ветпрепаратів та кормових добавок.

УДК 619:616.3-002-091:636.8

doi: 10.36359/scivp.2019-20-2.31

\title{
МІКРОСКОПІЧНІ ЗМІНИ В СЕЛЕЗІНЦІ КОТІВ, ЩО ЗАГИНУЛИ ВІД ІНФЕКЦІЙНОГО ПЕРИТОНІТУ
}

\author{
M. C. Kриштоп, аспірантка
}

Національний університет біоресурсів і природокористування України вул. Героїв оборони, 11, м. Київ, 03041, Україна

Представлені результати вивчення мікроскопічних змін у селезіниі котів, щзо загинули від інфекиійного перитоніту. При проведенні патологоанатомічного розтину в 19 котів нами була встановлена змішана форма інфекиійного перитоніту (73,1% випадків), а в 7 котів суха форма хвороби (26,9% випадків). При проведенні гістологічних досліджень селезінки нами було встановлено, щзо мікроскопічні зміни в цььому органі в усіх котів як при сухій, так $i$ при змішаній формах інфекиійного перитоніту були подібними та не залежали від тривалості прижиттєвого перебігу хвороби. В серозній оболониі реєструвалась виразна метаплазія клітин мезотелію та інфільтрація цієї оболонки моноцитами й лімфоцитами. $B$ червоній пульпі - майже повне зникнення еритроцитів, а в білій - різна ступінь гіперплазї лімфоїдни вузликів та їх гіпертрофія.

Ключові слова: КОТИ, ІНФЕКЦІЙНИЙ ПЕРИТОНІТ, СУХА ФОРМА, ЗМІШАНА ФОРМА, СЕЛЕЗІНКА, МІКРОСКОПІЧНІ ЗМІНИ.

Проблемам здоров’я котів нині приділяють значну увагу. Особливо значну роль у цьому плані мають інфекційні хвороби, в тому числі й інфекційний перитоніт [4]. У багатьох випадках єдиним методом точної прижиттєвої діагностики інфекційного перитоніту $\epsilon$ гістологічні дослідження біоптатів лімфовузлів чи внутрішніх органів. У частині випадків без 
гістологічних досліджень також не можна провести точну посмертну діагностику хвороби. Така діагностика зазвичай включає гістологічні дослідження печінки, нирок і кишкових лімфовузлів [5].

У доступній світовій літературі досить детально описані макроскопічні зміни за різних форм інфекційного перитоніту, а також мікроскопічні зміни в печінці нирках і кишкових лімфовузлах [3]. Поряд з цим мікроскопічні зміни в селезінці описані досить поверхнево.

Матеріали і методи. Патологоанатомічний розтин 26 трупів котів різних порід і віку, які загинули від інфекційного перитоніту, проводили методом часткової евісцерації [2]. При проведенні патологоанатомічного розтину для гістологічних досліджень відбирали шматочки селезінки.

Відібрані шматочки фіксували в 10 \% нейтральному (pH 7,2) водному розчині формаліну, зневоднювали в етанолах зростаючої концентрації $\left(60^{\circ}, 70^{\circ}, 80^{\circ}, 96^{0}, 100^{\circ}\right)$ і через хлороформ заливали в парафін. Зрізи товщиною 7 - 10 мкм одержували за допомогою санного мікроскопу. Одержані зрізи зафарбовували гематоксиліном Караці та еозином [1]. Одержані гістопрепарати вивчали під мікроскопом MC 100 LED (виробництво фірми «Micros», Австрія).

Результати й обговорення. При проведенні патологоанатомічного розтину в 19 котів нами була встановлена змішана форма інфекційного перитоніту $(73,1 \%)$, а в 7 котів - суха форма хвороби $(26,9 \%)$.

При проведенні гістологічних досліджень селезінки нами було встановлено, що мікроскопічні зміни в цьому органі в усіх котів як при сухій, так і при змішаній формах інфекційного перитоніту, були подібними та не залежали від прижиттєвої тривалості перебігу хвороби.

На поверхні капсули селезінки місцями виявлялись фібринозно-некротичні накладання. Подекуди в товщі таких накладань і між ними та капсулою селезінки виявлялись великі скупчення моноцитів і поодиноких макрофагів. Місцями під цими накладаннями серозна оболонка та сполучнотканинна капсула органу були повністю чи частково зруйновані.

У ділянках, де поверхні селезінки не була вкрита накладаннями, серозна оболонка органу місцями була не змінена. Вона була побудована з одного ряду мезотеліоцитів, під якими розташовувався надзвичайно тонкий прошарок пухкої волокнистої сполучної тканини. Клітини мезотелію являли собою сильно сплощені клітини 3 дуже витягнутим ядром. Співвідношення довгої та короткої осей цих клітин складало від $8: 1$ до $13: 1$. Довга вісь була орієнтована паралельно до зовнішньої поверхні селезінки перпендикулярно до довгої осі органу. Ядерно-цитоплазматичне співвідношення складало від $1: 1$ до $1: 3$.

Проте на багатьох ділянках реєструвалось виразна метаплазія клітин мезотелію. В останньому випадку сильно витягнуті вздовж зовнішньої поверхні селезінки плоскі мезотеліоцити спочатку помітно збільшувались у розмірах і дещо округлювались, набуваючи кубічної форми. На цій стадії метаплазії співвідношення довгої і короткої осей клітин складало від $1,5: 1$ до $2,5: 1$, а ядерно-цитоплазматичне співвідношення - від $1: 1$ до $1: 3$. Орієнтація клітин кардинально змінювалась: їх довга вісь була орієнтована перпендикулярно до зовнішньої поверхні селезінки. Цитоплазма змінених мезотеліоцитів ставала базофільною, ядра набували овальної чи неправильної форми, були досить інтенсивно зафарбовані гематоксиліном і містили 1 - 2 ядерця. В частині випадків спостерігалась дискомплексація поряд розташованих змінених мезотеліоцитів. Поодинокі змінені мезотеліоцити частково втрачали зв'язок і з базальною мембраною.

Надалі мезотеліоцити виразно збільшувались у розмірах і перетворювались на стовпчасті клітини. Співвідношення довгої і короткої осей таких клітин складало від 1,5 : 1 до $2,5: 1$, а ядерно-цитоплазматичне співвідношення - від $1: 1$ до $1: 2,5$. Їх довга вісь була орієнтована перпендикулярно до зовнішньої поверхні селезінки. Цитоплазма таких мезотеліоцитів також була виразно базофільною, ядра мали овальну, неправильну або округлу форму й містили $1-2$ ядерця. 
У ділянках метаплазії мезотеліоцитів серозна оболонка була нерівномірно інфільтрована поодинокими лімфоцитами й моноцитами.

У сполучнотканинній капсулі селезінки місцями реєструвались незначний іiї набряк. Такі зміни супроводжувались дискомплексацією та некрозом частини фібробластів. У трабекулах органу мікроскопічні зміни не виявлялися.

Натомість виразні мікроскопічні зміни нами були встановлені в пульпі селезінки. У червоній пульпі еритроцити майже не виявлялися. Натомість вона була нерівномірно інфільтрована великою кількістю моноцитів і меншою кількістю лімфоцитів. Місцями реєструвалась трансформація моноцитів у макрофаги.

Кількість лімфоїдних вузликів у селезінці збільшувалась, але ступінь такого збільшення був різним у різних тварин, що на нашу думку могло бути пов'язано як 3 індивідуальними особливостями функціонування імунної системи, так і з різним ступенем патогенної дії збудника хвороби. Проте в усіх випадках лімфоїдні вузлики селезінки були виразно гіпертрофовані. Така гіпертрофія відбувалась за рахунок збільшення кількості лімфоцитів, між якими місцями виявлялись поодинокі моноцити й макрофаги.

\title{
В И С Н О В К И
}

У селезінці котів, за змішаної і сухої форм інфекційного перитоніту, мікроскопічні зміни подібні. Мікроскопічно в серозній оболонці реєструється виразна метаплазія мезотеліоцитів та інфільтрація моноцитами й лімфоцитами. В червоній пульпі - майже повне зникнення еритроцитів, а в білій - різна ступінь гіперплазії лімфоїдних вузликів та їх гіпертрофія.

Перспективи досліджень. Будуть проведені гістологічні дослідження інших органів котів, що загинули за змішаної і сухої форм інфекційного перитоніту.

\section{MICROSCOPIC CHANGES IN THE SPLEEN OF CATS THAT DIED FROM THE INFECTIOUS PERITONITIS}

\author{
M. S. Kryshtop \\ National University of Life and Environmental Sciences of Ukraine, \\ 11, Gerojiv oborony str., Kyiv, 03041, Ukraine
}

S U M M A R Y

The results of study of microscopic changes in the spleen of cats died from the infectious peritonitis are presented. At the dissection in 19 cats, we have established a mixed form of infectious peritonitis ( $73.1 \%$ of cases), and in 7 cats - a dry form of the disease $(26.9 \%$ of cases). At the histological examination of the spleen, we found that the microscopic changes in this organ in all cats, both in dry and in mixed forms of infectious peritonitis, were similar and independent of the duration of the lifetime course of the disease. On the surface of the spleen capsule, fibrinous-necrotic mases appear in places. Somewhere in the thicker of such mases and between them and the capsule of the spleen, there were large clusters of monocytes and single macrophages. In places under these overlays, the serum and connective tissue capsule of the organ were completely or partially destroyed.

In the serosa was founded the pronounced metaplasia of mesothelium cells and the infiltration of the serosa by monocytes and lymphocytes. Mesothelial cells clearly increased in size and transformed into columnar cells. The ratio of long and short axes of such cells ranged from $1.5: 1$ to $2.5: 1$, and the nuclear-cytoplasmic ratio ranged from $1: 1$ to $1: 2.5$. Their long axis was oriented perpendicular to the spleen surface. The cytoplasm of these mesothelial cells was also distinctly basophilic, the nuclei had an oval, irregular or rounded form, and contained 1 to 2 nuclei. 
In the red pulp of the spleen, there was the almost complete disappearance of erythrocytes, and in white pulp of the spleen - a different degree of hyperplasia of lymphoid nodes and their hypertrophy.

Keywords: CATS, INFECTIOUS PERITONITIS, DRY FORM, MIXED FORM, SPLEEN, MICROSCOPIC CHANGES.

\title{
МИКРОСКОПИЧЕСКИЕ ИЗМЕНЕНИЯ В СЕЛЕЗЕНКЕ КОТОВ, УМЕРШИХ ОТ ИНФЕКЦИОННОГО ПЕРИТОНИТА
}

\author{
M. C. Kpummon
}

Национальный университет биоресурсов и природопользования Украины ул. Героев обороны, 11, г. Киев, 03041, Украина

\section{А Н Н О Т А ЦИ Я}

Представлены результаты изучения микроскопических изменений в селезенке котов, умерших от инфекционного перитонита. При патологоанатомическом вскрытии у 19 котов нами была установлены смешанная форма инфекционного перитонита ( $73,1 \%$ случаев), а у 7 котов - сухая форма этой болезни (26,9% случаев). При гистологических исследованиях селезенки нами было установлено, что микроскопические изменения в этом органе у всех котов как при сухой, так и при смешанной формах инфекционного перитонита были схожими и не зависели от длительности прижизненного течения болезни. В серозной оболочке регистрировались выраженная метаплазия клеток мезотелия и инфильтрация этой оболочки моноцитами и лимфоцитами. В красной пульпе - почти полное исчезновение эритроцитов, а в белой - разная степень гиперплазии лимфоидных узелков и их гипертрофия.

КлючевЫе слова: КОТЫ, ИНФЕКЦИОННЫЙ ПЕРИТОНИТ, СУХАЯ ФОРМА, СМЕШАННАЯ ФОРМА, СЕЛЕЗЕНКА, МИКРОСКОПИЧЕСКИЕ ИЗМЕНЕНИЯ.

\section{Л I T E P A T Y P A}

1. Горальський Л. П. Основи гістологічної техніки і морфофункціональні методи досліджень у нормі та при патології : навч. посіб. 2-ге вид. стер. / Л. П. Горальський, В. Т. Хомич, О. І. Кононський. - Ж. : Полісся, 2011. - 288 с.

2. Зон Г. А. Патологоанатомічний розтин тварин / Г. А. Зон, М. В. Скрипка, Л. Б. Іванівська. - Донецьк: ПП Глазунов Р.О., 2009. - 189 с.

3. Лісова B. B. Патологоанатомічні зміни за інфекційного перитоніту котів / В. В. Лісова, Н. М. Романенко, А. К. Овдій // Збірник наукових праць ЖНАЕУ - Житомир. 2012. - № 1 (32) . - Ч 2. - 3. - С. 338-341.

4. Ящук О. В. Моніторинг розповсюдження вірусів серед домашніх котів і собак у м. Дніпропетровськ / О. В. Ящук, Н. В. Черевач, А. І. Ванніков // Вісник Дніпропетровського університету. Біологія, медицина. - 2014. - № 5 (1). - С. 25-27.

5. Pedersen N. C. A review of feline infectious peritonitis virus infection: 1963-2008 / N. C. Pedersen // Journal of Feline Medicine and Surgery. - 2009. - V. 11, N 3. - P. 225-258.

\section{References}

1. Goralskij L. P., Homych V. T., \& Kononskij O. I. (2011). Osnovy histologichnoyi tehniky i morfofunkcionalni metody doslidjen u normi ta pry patologiyi. Jytomir, Polissya (in Ukrainian).

2. Zon G. A., Scripca M. V., \& Ivanivska L. B. (2009). Patologoanatomichniy rostin tvarin. Donezk, PP Glazunov R. O. (in Ukrainian). 
3. Lisova V. V., Romanenko N. M., \& Ovdiy A. K. (2012). Patologoanatomichny zminy za infekciynogo peritonitu cotiv. Scientific papers JNAEU, 1, 3, 338-341 (in Ukrainian).

4. Jashchuk O. V. (2014). Monitiring rospovsjudjennya virusiv sered domashnich cotiv i sobak u m. Dnepropetrovsk. Bulletin of Dnepropetrovsk University. Biology and medicine, 5, 23-27 (in Ukrainian).

5. Pedersen N. C. (2009). A review of feline infectious peritonitis virus infection: 1963-2008. Journal of Feline Medicine and Surgery, 11, 3, 225-258.

Рецензент - д. вет. н. О. П. Мельник, зав. кафедрою анатомії, гістології i патоморфології імені акад. В. Г. Касьяненка НУБіП України.

УДК 612.419:014.3:612.75

doi: 10.36359/scivp.2019-20-2.32

\title{
ХОНДРОГЕННЕ ДИФЕРЕНЦЮЮАННЯ МЕЗЕНХІМАЛЬНИХ СТОВБУРОВИХ КЛІТИН КРОЛЯ, ЗАЛЕЖНО ВІД ТИПУ КУЛЬТУРАЛЬНОЇ СИСТЕМИ
}

\author{
Ю. О. Харкевич ${ }^{1}$, канд. вет. наук, \\ Р. Р. Бокотько , канд. вет. наук, \\ А. Й. Мазуркевич ${ }^{l}$, д-р вет. наук, професор, \\ О. Г. Дерябіна ${ }^{2}$, канд. біол. наук, с. н. с.,

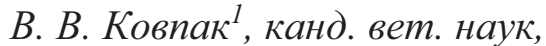 \\ М. О. Малюк', д-р вет. наук, доиент, \\ Л. В. Кладницька ${ }^{l}$ канд. вет. наук, доцент, \\ Ю. В. Дем'янцева ${ }^{1}$, аспірантка \\ ${ }^{1}$ Національний університет біоресурсів і природокористування України, \\ вул. Героїв Оборони, 15, м. Київ, 03041, Україна \\ ${ }^{2} Д У$ «Інститут генетичної та регенеративної медицини НАМН», \\ вул. Вишгородська, 67, м. Київ, 04114, Україна
}

Експериментальне вивчення здатності мезенхімальних стовбурових клітин до хондрогенного диференціювання іп vitro залежно від типу культуральної системи з метою їх подальшого клінічного застосування у ветеринарній медицині для відновлення втрачених функиій пошкодженого суглобового хряща є одним із пріоритетних напрямків наукових досліджень. Репаративна здатність хрящової тканини обмежена, оскільки рівень фізіологічної та репаративної регенерачії хрящової тканини досить низький. 3 огляду на це, триває пошук таких терапевтичних засобів та прийомів, які б дозволяли максимально ефективно відновити порушені структуру і функиію тканин суглобового хряща. Особливе місие у иьому пошуку належсть біотехнології. Мезенхімальні стовбурові клітини кісткового мозку - одна з найбільш вивчених мультипотентних популяцій клітин дорослого організму, яка завдяки здатності до проліфераиії $і$ диферениіювання in vitro, має вагоме значення $в$ клінічній ветеринарній практиці у лікуванні тварин з ураженнями суглобового хряща.

${ }^{6}$ Науковий керівник - д. вет. н., доцент М. О. Малюк 